\title{
Defoliation of strawberry mother plants for the production of runner tips
}

\author{
Miriane Dal Picio(1), Jerônimo Luiz Andriolo(1), Francieli Lima Cardoso(1), \\ Maíne Alessandra Lerner ${ }^{(1)}$ and Jéssica Maronez de Souza(1)
}

\begin{abstract}
(1) Universidade Federal de Santa Maria, Departamento de Fitotecnia, Avenida Roraima, $\mathrm{n}^{\circ}$ 1.000, Prédio 77, Campus Camobi, CEP 97105-900 Santa Maria, RS, Brazil. E-mail: mirianedalpicio@yahoo.com.br, jeronimoandriolo@gmail.com, franci-lc@hotmail.com, mainelerner@yahoo.com.br, jessica_maronez@hotmail.com
\end{abstract}

\begin{abstract}
The objective of this work was to determine the sink-source relationships and their effects on the number and growth of runner tips of 'Camino Real' strawberry stock plants. Three types of sources were evaluated: one defoliation at 96 days after planting (DAP), two defoliations at 50 and 96 DAP, and mother plants without defoliation. Four types of sink were accessed: runner tips collected weekly and monthly, four stolons with rooted runner tips in pots, and four freely-grown stolons. A completely randomized experimental design was used in a split-plot arrangement, with four replicates. The source types were placed in the plots, and sink types in the subplots. The number of runner tips, the crown diameter, and the dry matter mass were determined. Number and growth of tips were higher on plants without defoliation, and decreased $44.7 \%$ on twice-defoliated mother plants. The two-defoliation management did not reduce runner tip dry matter mass only on plants with rooted stolons, which produced runner tips 50\% heavier. Defoliation of mother plants bearing rooting stolons can be used to reduce their growth, without reducing the emission and growth of runner tips.
\end{abstract}

Index terms: Fragaria x ananassa, plug plants, propagation, sink strength, source-sink relationship.

\section{Desfolha de plantas matrizes de morangueiro para a produção de pontas de estolão}

Resumo - O objetivo deste trabalho foi determinar as relações dreno-fonte e seus efeitos sobre o número e o crescimento de pontas de estolões de plantas matrizes de morangueiro 'Camino Real'. Três tipos de fontes foram avaliadas: uma desfolha aos 96 dias após o plantio (DAP), duas desfolhas aos 50 e 96 DAP e plantas matrizes sem desfolha. Quatro tipos de drenos foram analisados: pontas de estolão coletadas semanal e mensalmente, quatro pontas enraizadas em vasos e quatro estolões de crescimento livre. Utilizou-se o delineamento experimental inteiramente casualizado com parcelas subdivididas e quatro repetições. Os tipos de fonte foram dispostos nas parcelas, e os tipos de dreno, nas subparcelas. Foram determinados o número de pontas, o diâmetro de coroa e a massa de matéria seca. O número e o crescimento das pontas foram mais elevados nas plantas sem desfolhamento, e diminuíram 44,7\% nas plantas matrizes com duas desfolhas. As duas desfolhas não reduziram a massa de matéria seca das pontas apenas nas plantas com estolões enraizados, as quais produziram pontas $50 \%$ mais pesadas. A desfolha das plantas matrizes com estolões enraizados pode ser usada para reduzir-lhes o crescimento, sem reduzir a emissão e o crescimento das pontas de estolão.

Termos para indexação: Fragaria x ananassa, mudas em bandejas, propagação, força de dreno, relação fonte-dreno.

\section{Introduction}

The potential crop yield depends mainly on photosynthetic efficiency, transport of carbon assimilates, and sink strength of plants. Nitrogen availability, the efficiency of solar radiation conversion into biomass, and the functional equilibrium between carbon and nitrogen are factors that affect source-sink relationships (Iqbal et al., 2012). They affect first the source strength, which in turn affects sink strength and the $\mathrm{C}$ and $\mathrm{N}$ economy of plants.

Leaf surface has an essential role for plant potential photosynthetic capacity and crop yield (Paul \& Foyer, 2001). Defoliation, defined as partial or whole removal of plant leaves, is a technique that has been used in several regions of the world for stimulating the photosynthesis and growth of young leaves, promoting a better use of water and nutrients and also modifying 
the dry matter partitioning between source and sink compartments of plants (Khan et al., 2007; Iqbal et al., 2012). Chanishvili et al. (2005) argued that defoliation is a useful tool for the management of plant source-sink equilibrium, and can also be used by researchers for simulating dry matter partitioning among plant organs.

The effect of partial and whole defoliation on plant growth and crop yield has been determined mainly in Poaceae grasses and fruiting crops. In strawberry, it has been used after harvesting in two-year crops, for reducing diseases and pests. Daugaard et al. (2003) reported that defoliation reduced the incidence of Botrytis cinerea and slightly increased fruit size in the following cropping periods. Albregts et al. (1992) argued that defoliation can also be used in the production of strawberry transplants, to reduce pests and diseases, and to lower transpiration during transport and planting, provided that further plant growth and fruit yield will not be reduced.

Strawberry stolons can act as individual plants, as reported by Alpert et al. (2003). When connected to the mother plant, they can also exchange carbon, water, mineral nutrients, and biochemical compounds by vascular transport (Holzapfel \& Alpert, 2003). In heterogeneous environments, the stolon connections among clonally propagated plants can enhance plant adaptation and survival (Alpert et al., 2003). Root growth was higher in Fragaria chiloensis plants connected by stolons, grown under low radiation and high $\mathrm{N}$ availability; whereas the effect was inversed in plants grown without stolons (Roiloa et al., 2007). In Fragaria orientalis, the growth of stressed mother plants was compensated by connected stolons (Zhang et al., 2009). In spite the existence of these studies on strawberry wild species, no similar records were found for the cultivated species Fragaria x ananassa. A vigorous growth of mother plants was reported during the propagation phase of this species for producing runner tips (Dal Picio et al., 2013), which represents a waste of carbon assimilates, water and mineral nutrients. Therefore, it can be hypothesised that defoliation can be used to reduce growth of mother plants, without reducing emission and growth of runner tips for plug transplant production.

The objective of this work was to determine sink-source relationships and their effects on the number and growth of runner tips by strawberry 'Camino Real' stock plants.

\section{Materials and Methods}

The experiment was conducted inside a polyethylene umbrella greenhouse, at Departamento de Fitotecnia, Universidade Federal de Santa Maria, Santa Maria, RS, Brazil, from October $13^{\text {th }}, 2011$ to April $16^{\text {th }}$, 2012. Mean air temperature and accumulated daily global solar radiation, measured by an automatic meteorological station placed $800 \mathrm{~m}$ away from the greenhouse, were: $19.91^{\circ} \mathrm{C}$ and $382.63 \mathrm{MJ} \mathrm{m}^{-2}$, in October, respectively; $22.11^{\circ} \mathrm{C}$ and $718.86 \mathrm{MJ} \mathrm{m}^{-2}$, in November; $23.03^{\circ} \mathrm{C}$ and $754.49 \mathrm{MJ} \mathrm{m}^{-2}$, in December; $25.28^{\circ} \mathrm{C}$ and $775.81 \mathrm{MJ} \mathrm{m}^{-2}$, in January; $25.88^{\circ} \mathrm{C}$ and $564.81 \mathrm{MJ} \mathrm{m}^{-2}$, in February; $22.59^{\circ} \mathrm{C}$ and 621.92 $\mathrm{MJ} \mathrm{m}^{-2}$, in March; and $21.10^{\circ} \mathrm{C}$ and $245.83 \mathrm{MJ} \mathrm{m}^{-2}$, in April.

Stock plants of 'Camino Real' strawberry, obtained from the micropropagation laboratory, were planted in $1.7 \mathrm{dm}^{3}$ polyethylene pots, placed over $0.80 \mathrm{~m}$ height benches, at a density of 9 plants $\mathrm{m}^{-2}$. It was used an organic substrate Mecplant HF with $60 \%$ water retaining capacity and $375 \mathrm{~g} \mathrm{dm}^{-3}$ bulk density. Estimated daily water absorption was based on solar radiation and on the crop coefficient for drip irrigation (Timm et al., 2009), with a drainage coefficient of about $30 \%$. Plants were fertigated by drippers five times a day during five min, using a standard nutrient solution at the following concentrations $\left(\mathrm{mmol} \mathrm{L}^{-1}\right)$ : $10.60 \mathrm{NO}_{3}^{-} ; 0.43 \mathrm{NH}_{4}^{+} ; 2.00 \mathrm{H}_{2} \mathrm{PO}_{4}^{-} ; 6.15 \mathrm{~K}^{+} ; 3.00 \mathrm{Ca}^{2+}$; $1.00 \mathrm{Mg}^{2+}$ and $1.00 \mathrm{SO}_{4}^{2+}$, and in $\mathrm{mg} \mathrm{L}^{-1}: 0.03 \mathrm{Mo}$; $0.42 \mathrm{~B} ; 0.06 \mathrm{Cu} ; 0.50 \mathrm{Mn} ; 0.22 \mathrm{Zn}$; and $1.00 \mathrm{Fe}$.

Three types of sources (mother plants) and four types of sinks were evaluated in a completely randomized design, in a split-plot arrangement with four replicates of three plants per treatment. Sources were placed in the plots, and sinks in the subplots. The following source types were evaluated: no defoliation of plants (control) (A); one defoliation of plants at 96 days after planting (B); and two defoliations at 50 and 96 days after planting (C). The sink types were: $\mathrm{T} 1$, runner tips collected weekly, similarly as when producing plug plants; T2, runner tips collected and counted at 30-day intervals; T3, four runner tips rooted in pots, originating four daughter plants kept connected to the mother plant by stolons and grown at nine plants per square meter (mothers and daughters); and T4, four stolons of the mother plant growing freely. Runner tips emitted by mother plants and by the stolons were collected and counted at weekly intervals. 
Defoliation of mother plants was done by picking up all leaves when the petioles of the two older leaves ceased to grow in weekly measurements of petiole length. The crown diameter of collected runner tips was measured with a pachymeter, and dry matter mass was determined after drying at $65^{\circ} \mathrm{C}$, until constant weight was reached. At the ending date (April $16^{\text {th }}$, 2012), four mother plants of all treatments were collected to determine shoot, root and crown dry matter mass. Data were evaluated by analysis of variance, after transforming discrete data by $(\mathrm{x}+0.5)^{0.5}$, using Statistica software .

\section{Results and Discussion}

The total number of runner tips did not differ significantly among source types (Table 1 ). On mother plants without defoliation, the number of tips was higher when they were monthly collected. Growth of runner tips was higher when they were collected monthly from plants without defoliation, and decreased $44.7 \%$ on twice-defoliated mother plants. The runner tip growth was not significantly affected by defoliation on mother plants with four stolons attached, rooted or unrooted. Total dry matter mass of runner tips was affected by defoliation; it was higher on nondefoliated plants, when tips were collected weekly, and lower on twice-defoliated plants bearing four unrooted stolons.

Interaction between sources and sinks were observed for the crown diameter of runner tips. Higher crown diameter was recorded on nondefoliated plants with tips collected weekly, and lowered $24.3 \%$ on twice-defoliated plants. Nevertheless, the effect of two defoliations on crown diameter was partially compensated by rooting stolons, being $12.4 \%$ higher than in plants with unrooted stolons.

The number of runner tips did not differ significantly among source types, which highlights that it is a developmental plant variable affected mainly by photoperiod and temperature (Smeets, 1980; Sonsteby, 1997). Nevertheless, their growth differs according to source-sink relationship. When tips were collected weekly, their growing period was shorter that when they were collected monthly. The plant growth process follows an exponential curve, their young leaves act as sinks, and the aged ones act like sources (Iqbal et al., 2012). This implies that tips growing for only one week before being collected depend more on assimilates from the mother stock plant than those growing during one month. Nevertheless, only young tips bearing root primordia can be used for the production of plug transplants from runner tips (Lieten, 1998; Poling \& Maas, 1998), and higher number of tips collected monthly is not a true advantage, because most of them are too aged and have to be discarded. Considering that tips emitted early in the spring can be used for multiplying stock plants for further production of tips (Dal Picio et al., 2012), the weekly period should be retained for the production of strawberry plug transplants.

The total number of runner tips was higher on plants with rooted stolons, and it was not significantly affected by defoliation (Table 2). Without defoliation, the total number of tips on T3 was $56.8 \%$ higher than on T4 plants; with one defoliation, $49.1 \%$ higher than on T3 plants; and with two defoliations, $67.3 \%$ higher than on plants. Similar effects were recorded for total dry matter mass of runner tips. The mean dry matter mass of tips was also not reduced on twice-defoliated plants,

Table 1. Total number of runner tips per mother plant, total dry matter mass, and crown diameter of runner tips of strawberry 'Camino Real' mother plants without defoliation (A), with one defoliation at 96 days after planting (B), or with two defoliations at 50 and 96 days after planting (C), with four types of $\operatorname{sink}^{(1)}$.

\begin{tabular}{|c|c|c|c|c|c|c|c|c|c|}
\hline \multirow[t]{2}{*}{ Sink type ${ }^{(2)}$} & \multicolumn{3}{|c|}{$\mathrm{N}^{\circ}$ of runner tips per plant } & \multicolumn{3}{|c|}{ Total dry matter mass (g) } & \multicolumn{3}{|c|}{ Crown diameter $(\mathrm{mm})$} \\
\hline & A & B & $\mathrm{C}$ & A & B & $\mathrm{C}$ & A & B & $\mathrm{C}$ \\
\hline $\mathrm{T} 1$ & $64.50 \mathrm{ABa}$ & $69.50 \mathrm{Aa}$ & $64.42 \mathrm{Aa}$ & $45.14 \mathrm{Ba}$ & $38.50 \mathrm{Bab}$ & $23.60 \mathrm{ABb}$ & $5.30 \mathrm{Aa}$ & $4.71 \mathrm{ABb}$ & $4.01 \mathrm{Bc}$ \\
\hline $\mathrm{T} 2$ & $91.33 \mathrm{Aa}$ & $81.25 \mathrm{Aa}$ & $70.33 \mathrm{Aa}$ & $74.32 \mathrm{Aa}$ & $62.84 \mathrm{Aa}$ & $41.12 \mathrm{Ab}$ & $4.84 \mathrm{ABa}$ & $5.06 \mathrm{Aa}$ & $4.90 \mathrm{Aa}$ \\
\hline $\mathrm{T} 3$ & $47.58 \mathrm{Ba}$ & $54.25 \mathrm{Aa}$ & $56.25 \mathrm{Aa}$ & $28.02 \mathrm{Ba}$ & $30.94 \mathrm{Ba}$ & $25.22 \mathrm{ABa}$ & 5.19ABa & 4.89ABa & $4.75 \mathrm{Aa}$ \\
\hline $\mathrm{T} 4$ & $48.08 \mathrm{Ba}$ & $52.50 \mathrm{Aa}$ & 45.92Aa & $25.59 \mathrm{Ba}$ & $25.88 \mathrm{Ba}$ & $16.13 \mathrm{Ba}$ & $4.74 \mathrm{Ba}$ & 4.52Bab & $4.16 \mathrm{Bc}$ \\
\hline $\mathrm{CV}(\%)$ & & 24.27 & & & 29.82 & & & 9.43 & \\
\hline
\end{tabular}

${ }^{(1)}$ Means followed by equal letters, lowercase in the rows and uppercase in the columns, do not differ, by Tukey's test, at $5 \%$ probability. ${ }^{(2)} \mathrm{T} 1$ and T2, weekly and monthly collected tips, respectively; and T3 and T4, four stolons weekly collected with rooted and unrooted tips, respectively. 
and the lowest value was recorded for plants bearing unrooted stolons. Moreover, the crown diameter of tips was only affected by rooting, and not by defoliation. These results confirm the findings in the literature, which report that the mother plant and its rooted stolons can reciprocally exchange carbon, water, and nutrients as a unique growing system (Savini et al., 2008; Mao et al., 2009). Nevertheless, this applies only to rooted stolons; unrooted ones act as sinks, and their survival and growth depend on the mother plant.

The number of runner tips produced from January to April, the best period for plug plant production to be sold by nurseries, was not significantly affected by defoliation, but it was affected by sink types (Table 3 ). Although defoliation did not significantly affect the number of tips, it was 15.4 and $20 \%$ higher on onceand twice-defoliated plants, respectively. The effect of defoliation on total dry matter mass was higher on once- and twice-defoliated plants with rooted stolons. Dry matter mass of runner tips was not reduced by the use of two defoliations only on plants with rooted stolons, and it was 50\% higher on those. Rooting stolons also enhanced crown diameter of tips.
On twice-defoliated plants, the emission of runner tips was delayed. In the whole experimental period, from November to April, 65.6\% tips were emitted from January to April, on $\mathrm{T} 1$, and $73.2 \%$ on $\mathrm{T} 3$. On nondefoliated plants, fractions were 54.3 and $64.6 \%$, respectively. Although the number of tips is a developmental character affected by the environment, it is also affected by sink-source relationships. In fact, the emission of stolons depends on developmental variables, while their growth depends on carbon assimilates. On nondefoliated plants with tips weekly collected and with rooted stolons, leaf area for photosynthesis and root surface for water and nutrient uptake were greater, confirming the unique growing system of the mother plant and its rooted stolons.

At the end of the experiment, there were interactions among growth variables and treatments (Table 4). Total dry matter mass was higher on nondefoliated plants. Twice-defoliated plants differed from once-defoliated ones only when tips were collected weekly. On nondefoliated plants, a lower growth was recorded on those bearing unrooted stolons, differing from those with rooted stolons and from those without

Table 2. Total number of runner tips per mother plants, total dry matter mass and crown diameter of runner tips of strawberry 'Camino Real' mother plants without defoliation (A), with one defoliation at 96 days after planting (B), or with two defoliations at 50 and 96 days after planting (C), plus daughter plants and two types of $\operatorname{sink}^{(1)}$.

\begin{tabular}{|c|c|c|c|c|c|c|c|c|c|}
\hline \multirow{2}{*}{$\begin{array}{l}\text { Sink } \\
\text { type }{ }^{(2)}\end{array}$} & \multicolumn{3}{|c|}{$\mathrm{N}^{\circ}$ of runner tips per plant } & \multicolumn{3}{|c|}{ Total dry matter mass (g) } & \multicolumn{3}{|c|}{ Crown diameter (mm) } \\
\hline & A & B & $\mathrm{C}$ & A & B & $\mathrm{C}$ & A & $\mathrm{B}$ & $\mathrm{C}$ \\
\hline $\mathrm{T} 3$ & $119.17 \mathrm{Aa}$ & $133.00 \mathrm{Aa}$ & $131.92 \mathrm{Aa}$ & $101.83 \mathrm{Aa}$ & $114.06 \mathrm{Aa}$ & $98.85 \mathrm{Aa}$ & $5.78 \mathrm{Aa}$ & $5.63 \mathrm{Aa}$ & $5.40 \mathrm{Aa}$ \\
\hline T4 & $76.00 \mathrm{Ba}$ & $89.17 \mathrm{Ba}$ & $78.83 \mathrm{Ba}$ & $37.20 \mathrm{Ba}$ & $42.92 \mathrm{Ba}$ & $29.68 \mathrm{Ba}$ & $4.61 \mathrm{Ba}$ & $4.38 \mathrm{Ba}$ & $4.23 \mathrm{Ba}$ \\
\hline CV (\%) & & 21.92 & & & 24.63 & & & 8.39 & \\
\hline
\end{tabular}

${ }^{(1)}$ Means followed by equal letters, lowercase in the rows and uppercase in the columns, do not differ, by Tukey's test, at $5 \%$ probability. ${ }^{(2)} \mathrm{T} 3$ and $\mathrm{T} 4$, four stolons weekly collected with rooted and unrooted tips, respectively.

Table 3. Total number and crown diameter of runner tips produced from January to April 2012 by strawberry 'Camino Real' mother plants without defoliation (A), with one defoliation at 96 days after planting (B), or with two defoliations at 50 and 96 days after planting $(\mathrm{C})$, plus daughter plants and four types of $\operatorname{sink}^{(1)}$.

\begin{tabular}{|c|c|c|c|c|c|c|c|c|c|}
\hline \multirow{2}{*}{$\begin{array}{l}\text { Sink } \\
\text { type }^{(2)}\end{array}$} & \multicolumn{3}{|c|}{$\mathrm{N}^{\circ}$ of runner tips per plant } & \multicolumn{3}{|c|}{ Total dry matter mass (g) } & \multicolumn{3}{|c|}{ Crown diameter $(\mathrm{mm})$} \\
\hline & $\mathrm{A}$ & B & $\mathrm{C}$ & A & B & $\mathrm{C}$ & $\mathrm{A}$ & B & $\mathrm{C}$ \\
\hline T1 & $35.08 \mathrm{Ba}$ & $37.67 \mathrm{Ba}$ & $42.25 \mathrm{Ba}$ & $25.99 \mathrm{Ba}$ & $20.61 \mathrm{Ba}$ & $16.70 \mathrm{Ba}$ & $5.30 \mathrm{Ba}$ & $4.67 \mathrm{Bb}$ & $3.99 \mathrm{Cc}$ \\
\hline $\mathrm{T} 2$ & $70.33 \mathrm{Aa}$ & $61.92 \mathrm{ABa}$ & $48.92 \mathrm{Ba}$ & $55.08 \mathrm{Aa}$ & $44.61 \mathrm{Bab}$ & $24.01 \mathrm{Bb}$ & $4.86 \mathrm{Ba}$ & $5.02 \mathrm{Ba}$ & $4.89 \mathrm{Ba}$ \\
\hline $\mathrm{T} 3$ & $76.92 \mathrm{Aa}$ & $90.92 \mathrm{Aa}$ & $96.58 \mathrm{Aa}$ & $76.32 \mathrm{Aa}$ & $88.20 \mathrm{Aa}$ & $83.15 \mathrm{Aa}$ & $6.04 \mathrm{Aa}$ & $5.73 \mathrm{Aa}$ & $5.77 \mathrm{Aa}$ \\
\hline $\mathrm{T} 4$ & $45.08 \mathrm{ABa}$ & $54.50 \mathrm{Ba}$ & $56.67 \mathrm{Ba}$ & $24.44 \mathrm{Ba}$ & $28.81 \mathrm{Ba}$ & $23.02 \mathrm{Ba}$ & 4.77Ba & $4.44 \mathrm{Ba}$ & 4.33BCa \\
\hline$\overline{\mathrm{CV}(\%)}$ & & 28.94 & & & 30.33 & & & 8.70 & \\
\hline
\end{tabular}

${ }^{(1)}$ Means followed by equal letters, lowercase in the rows and uppercase in the columns, do not differ, by Tukey's test, at 5\% probability. ${ }^{(2)} \mathrm{T} 1$, weekly collected types; T2, monthly collected tips; T3 and T4, four stolons weekly collected with rooted and unrooted tips, respectively. 
Table 4. Dry matter mass of crown, shoots, and roots at the end of the experimental period, on 'Camino Real' strawberry mother plants without defoliation (A), with one defoliation at 96 days after planting (B), or with two defoliations at 50 and 96 days after planting $(\mathrm{C})$, with four types of $\operatorname{sink}^{(1)}$.

\begin{tabular}{|c|c|c|c|c|c|c|c|c|c|}
\hline \multirow{2}{*}{$\begin{array}{l}\text { Sink } \\
\text { type }^{(2)}\end{array}$} & \multicolumn{3}{|c|}{ Crown dry matter mass (g per plant) } & \multicolumn{3}{|c|}{ Shoot dry matter mass (g per plant) } & \multicolumn{3}{|c|}{ Root dry matter mass (g per plant) } \\
\hline & A & B & $\mathrm{C}$ & A & B & $\mathrm{C}$ & A & B & $\mathrm{C}$ \\
\hline $\mathrm{T} 1$ & 15.12Aab & $23.08 \mathrm{Aa}$ & $11.67 \mathrm{Bb}$ & $151.65 \mathrm{Aa}$ & $64.10 \mathrm{ABb}$ & $44.94 \mathrm{ABb}$ & $33.83 \mathrm{Aa}$ & $16.77 \mathrm{ABb}$ & $10.53 \mathrm{Bb}$ \\
\hline $\mathrm{T} 2$ & $11.60 \mathrm{Aa}$ & $11.36 \mathrm{Ba}$ & $8.30 \mathrm{Ba}$ & 130.27Aa & $38.15 \mathrm{Bb}$ & $28.45 \mathrm{Bb}$ & $27.06 \mathrm{Aa}$ & $12.27 \mathrm{Bb}$ & $6.48 \mathrm{Bb}$ \\
\hline $\mathrm{T} 3$ & $11.85 \mathrm{Ab}$ & $22.42 \mathrm{Aa}$ & $22.64 \mathrm{Aa}$ & $137.69 \mathrm{Aa}$ & $75.62 \mathrm{Ab}$ & $70.37 \mathrm{Ab}$ & $25.18 \mathrm{Aa}$ & $21.70 \mathrm{ABa}$ & $20.25 \mathrm{Aa}$ \\
\hline $\mathrm{T} 4$ & $9.95 \mathrm{Aa}$ & $13.45 \mathrm{Ba}$ & $9.72 \mathrm{Ba}$ & $99.21 \mathrm{Ba}$ & $48.72 \mathrm{Bb}$ & $37.34 \mathrm{Bb}$ & $24.61 \mathrm{Aa}$ & $24.23 \mathrm{Aa}$ & $14.42 \mathrm{ABb}$ \\
\hline $\mathrm{CV}(\%)$ & & 31.85 & & & 18.83 & & & 24.97 & \\
\hline
\end{tabular}

${ }^{(1)}$ Means followed by equal letters, lowercase in the rows and uppercase in the columns, do not differ, by Tukey's test, at $5 \%$ probability. ${ }^{(2)} \mathrm{T} 1$, weekly collected tips; T2, monthly collected tips; and T3 and T4, four stolons weekly collected with rooted and unrooted tips, respectively.

stolons, with tips collected weekly. On once-defoliated plants, the growth of the ones with tips collected weekly was similar to those with rooted stolons. On twice-defoliated plants, rooting stolons were able to compensate for the growth reduction caused by defoliation. On plants with rooted stolons, the growth of the crown on nondefoliated plants was 47.1 and $47.6 \%$ lower than on the once- and twice-defoliated ones, respectively. Shoot dry matter mass was higher on nondefoliated plants, and it was reduced on plants bearing unrooted stolons. As to defoliated plants, shoot growth was higher on the ones with rooted stolons than on those with unrooted stolons and on those with stolons monthly collected.

Root growth was most reduced by defoliation on plants with tips collected monthly, and it was not affected in plants with rooted stolons. The highest growth of mother plants was reached by plants without defoliation, and it did not affect the number of tips produced neither during all the growing period nor in the January-April period. On twice-defoliated mother plants, the crown diameter was reduced. This was a source limitation effect not recorded on tips collected monthly because, on tips growing for a longer period, this source activity is increased. However, it has been reported in the literature that the crown diameter of tips did not affect further growth and fruit yield of plants (Cocco et al., 2011). In the soilless production of tips for plug transplants, the growth of mother plant is not a matter of interest because mother plants should be discarded at the end of the tip production period. This would be an advantage only in the case that such plants were to be used for further production of fruit, as suggested by Dal Picio et al. (2013). Nevertheless, these authors showed that, although high fruit yield can be reached by mother plants after tip production, fruit size is reduced. For agronomic purposes in the commercial production of tips for plug transplants, two defoliations combined with rooting stolons seem to be the better practice.

\section{Conclusions}

1. The number and the growth of strawberry runner tips emitted by mother plants are affected by source-sink relationships; stolons and tips acting as sinks.

2. When stolons are rooted, they can act as sources and exchange carbon, water, and nutrients with the stock plant.

\section{Acknowledgments}

To Conselho Nacional de Desenvolvimento Científico e Tecnológico (CNPq), for financial support; and to Coordenação de Aperfeiçoamento de Pessoal de Nível Superior (Capes), for scholarship granted.

\section{References}

ALBREGTS, E.E.; HOWARD, C.M.; CHANDLER, C.K. Defoliation of strawberry transplants for fruit production in Florida. Hortscience, v.27, p.889-891, 1992.

ALPERT, P.; HOLZAPFEL, C.; SLOMINSKI, C. Differences in performance between genotypes of Fragaria chiloensis with different degrees of resource sharing. Journal of Ecology, v.91, p.27-35, 2003. DOI: 10.1046/j.1365-2745.2003.00737.x.

CHANISHVILI, S.S.; BADRIDZE, G.S.; BARBLISHVILI, T.F.; DOLIDZE, M.D. Defoliation, photosynthetic rates, and assimilate transport in grapevine plants. Russian Journal of Plant Physiology, v.52, p.448-453, 2005. DOI: 10.1007/s11183-005-0066-x.

COCCO, C.; ANDRIOLO, J.L.; CARDOSO, F.L.; ERPEN, L.; SCHMITT, O.J. Crown size and transplant type on the 
strawberry yield. Scientia Agricola, v.68, p.489-493, 2011. DOI: 10.1590/S0103-90162011000400015.

DAL PICIO, M.; ANDRIOLO, J.L.; ERPEN, L.; JANISCH, D.I.; SCHMITT, O.J. Multiplication of strawberry stock plants at different planting times. Horticultura Brasileira, v.30, p.544-548, 2012. DOI: 10.1590/S0102-05362012000300031.

DAL PICIO, M.; ANDRIOLO, J.L.; JÄNISCH, D.I.; SCHMITT, O.J.; LERNER, M.A. Fruit yield of strawberry stock plants after runner tip production by different cultivars. Horticultura Brasileira, v.31, p.375-379, 2013. DOI: 10.1590/ S0102-05362013000300006.

DAUGAARD, H.; SØRENSEN, L.; LØSCHENKOHL, B. Effect of plant spacing, nitrogen fertilisation, post-harvest defoliation and finger harrowing in the control of Botrytis cinerea Pers. in strawberry. European Journal of Horticultural Science, v.68, p.77-82, 2003.

HOLZAPFEL, C.; ALPERT, P. Root cooperation in a clonal plant: connected strawberries segregate roots. Oecologia, v.134, p.72-77, 2003. DOI: 10.1007/s00442-002-1062-x.

IQBAL, N.; MASOOD, A.; KHAN, N.A. Analyzing the significance of defoliation in growth, photosynthetic compensation and source-sink relations. Photosynthetica, v.50, p.161-170, 2012. DOI: 10.1007/s11099-012-0029-3.

KHAN, N.A.; SINGH, S.; NAZAR, R.; LONE, P.M. The source-sink relationship in mustard. The Asian and Australasian Journal of Plant Science and Biotechnology, v.1, p.10-18, 2007.

LIETEN, F. Recent advances in strawberry plug transplant technology. Acta Horticulturae, v.513, p.383-388, 1998.

MAO, S.-Y.; JIANG, C.-D.; ZHANG, W.-H.; SHI, L.; ZHANG, J.; CHOW, W.S.; YANG, J. Water translocation between ramets of strawberry during soil drying and its effects on photosynthetic performance. Physiologia Plantarum, v.137, p.225-234, 2009. DOI: 10.1111/j.1399-3054.2009.01275.x.

PAUL, M.J.; FOYER, C.H. Sink regulation of photosynthesis. Journal of Experimental Botany, v.52, p.1383-1400, 2001. DOI: 10.1093/jexbot/52.360.1383.

POLING, E.B.; MAAS, J.L. Strawberry plug transplant technology. Acta Horticulturae, v.513, p.393-401, 1998.

ROILOA, S.R.; ALPERT, P.; THARAYIL, N.; HANCOCK, G.; BHOWMIK, P.C. Greater capacity for division of labour in clones of Fragaria chiloensis from patchier habitats. Journal of Ecology, v.95, p.397-405, 2007. DOI: 10.1111/j.1365-2745.2007.01216.x.

SAVINI, G.; GIORGI, V.; SCARANO, E.; NERI, D. Strawberry plant relationship through the stolon. Physiologia Plantarum, v.134, p.421-429, 2008. DOI: 10.1111/j.1399-3054.2008.01145.x.

SMEETS, L. Effect of temperature and daylength on flower initiation and runner formation in two everbearing strawberry cultivars. Scientia Horticulturae, v.12, p.19-26, 1980. DOI: 10.1016/0304-4238(80)90034-5.

SONSTEBY, A. Short-day period and temperature interactions on growth and flowering of strawberry. Acta Horticulturae, n.439, p.609-616, 1997.

TIMM, L.C.; TAVARES, V.E.Q.; REISSER JÚNIOR, C.; ESTRELA, C.C. Morangueiro irrigado: aspectos técnicos e ambientais do cultivo. Pelotas: Ed. da UFPEL, 2009. 163p.

ZHANG, Y.C.; ZHANG Q.; LUO, P.; WU, N. Photosynthetic response of Fragaria orientalis in different water contrast clonal integration. Ecological Research, v.24, p.617-625, 2009. DOI: 10.1007/s11284-008-0533-X

Received on December 9, 2013 and accepted on June 25, 2014 